Gritcyuk $\mathbf{k}$.

\title{
FORECASTING OF PRODUCTION COST AND OTHER INDICES OF ACTIVITY OF INDUSTRIAL ENTERPRISE
}

Досліджено взаємозв'язок між собівартістю реалізованої продукції і операційними витратами, а також між чистим доходом та собівартістю реалізованої продукції деяких промислових підприємств. Розроблено економіко-математичні моделі у вигляді рівняння множинної регресії на основі статистичних даних кількох промислових підприємств України. Перевірено адекватність моделей експериментальним даним.

Ключові слова: економіко-математичні моделі, рівняння множинної регресії, множинні коефiцієнти корелящії і детермінації.

\section{Introduction}

Increasing the efficiency of the enterprise activity is an important problem in the modern economic conditions. To identify the reserves in the enterprise activity it is necessary to eliminate problematic places in the enterprise activity, rationally manage the enterprise resources.

When creating an expenses forecast of the enterprise it is necessary to qualitatively and quantitatively evaluate the indices which characterize the studied phenomenon and processes.

The cost of production is one of the most important indices of the work of the enterprise, since it shows how effectively it functions. It reflects all the economic activities of the enterprise, the results of using of all the resources of the enterprise. The financial results of the enterprise activity, the pace of extended recreation, the financial status of subjects of management, the competitiveness of production are depend from level of resources of the enterprise [1]. The lower it is, the more effectively the material, labor and other resources of the enterprise are used.

The cost price of the enterprise production consists of the costs of natural resources, raw materials, materials, fuel, energy, fixed assets, labor resources and other costs [2]. An analysis of the production cost (works, services) is an important tool in the cost management system.

It is important to determine the factors on the basis of existing scientific-methodological approaches that have the greatest impact on the cost of sales and other indices of the enterprise activity, to determine the type of equations describing the dependence of the change of indices of the enterprise activity from the changes in these factors, and the parameters of these equations. It is necessary to build models which are adequate to experimental data, which can then be used to analyze, forecast and manage the indices of the enterprise activity in the system of efficient using of enterprise resources.

\section{The object of research and its technological audit}

Forecasting of the cost of sales, income of Ukrainian enterprises on the basis of statistical data of several enterprises is the object of research.
Forecasting of the cost price and other economic indices of the enterprise activity is a scientific analysis of tendencies in the activity of the enterprise, identifying factors which affect on its formation. The most accurate and developed method of forecasting is regression analysis.

Since economic-mathematical models of the indices of the enterprise activity of Ukrainian enterprises are built for a small number of enterprises, it is necessary to build these models on the basis of an analysis of available scientificmethodological approaches, as well as statistical data from several Ukrainian enterprises. This will help in creating forecasts of production cost and other economic indices of the enterprise activity. This will also outline ways to reduce the production cost and, consequently, improve the profitability of enterprises, increase their profits and the welfare of employees of enterprises.

\section{The aim and objectives of research}

Development of the economic-mathematical models for the forecasting of cost of sales and the income of enterprises of dairy and construction industry of Ukraine is the aim of research.

It is necessary to solve the following tasks for this:

1. To carry out an analysis of the cost of sales of dairy and construction industry enterprises of Ukraine.

2 . To construct the regression equation which will describe the relationship between the cost of sales and the factors which affect on its result, as well as between net income of enterprise and cost of sales.

3. To found multiple coefficients of correlation $R$ and determination $R^{2}$, which determine the adequacy of the models to experimental data, the value of $F$-statistics of the $T$-criterion for estimating the significance of the model and the correlation coefficient.

4. To construct linear and polynomial trends for forecasting of the net income of construction industry enterprise during several years ahead.

\section{Research of existing solutions of the problem}

There are a large number of sources, in which the economic-mathematical approach to the analysis of the 
production cost and other indices of the enterprise activity is considered.

In [1], the dependence of the financial results of the enterprise activity on the production cost is considered.

In [2] it is considered from what expenses the cost price of production of the enterprise is consist. The grouping of expenses by their economic content is given in [3]. The composition, structure and factors which determine the production cost are considered in [4]. Correlation-regression analysis is often used to analyze the indices of enterprise activity [5-9]. The basis of the most frequently used in the correlation-regression analysis method of ordinary least squares (OLS) is considered in [10-12].

However, taking into account existing research, the issue of forecasting the indices of activity of industrial enterprise in Ukraine and other countries has not been given enough attention. In many researches, a detailed verification of the adequacy of the constructed models to experimental data and the significance of models and correlation coefficients has not carried out. Thus, in [9] there is not carried out the verification of the significance of developed models and correlation coefficients with help of finding the quantiles of the Fisher-Snedecor distribution and the Student distribution. Often the construction of models is not based on the actual statistics of the enterprise. It is also important to build trends for forecasting the indices of enterprise activity during years ahead, to which small number of researches has been devoted.

\section{Methods of research}

The management of the cost of commodity products is one of the key moments in the process of daily management of the enterprise from the side of resource saving and profitability.

Economic-mathematical modeling and forecasting of the cost of commodity products of the enterprise enables effective analysis of complex situations associated with the making of strategic decisions and control for their carrying out. It allows foreseeing a large number of situations, and this helps to use existing resources more effectively, reduce the level of future risks and losses.

The model of managing the costs of commodity products of business entity is individual for each enterprise. The application of these models makes it possible to give the recommendations for managing its activities at various levels of the hierarchy for the head managers of enterprise. These recommendations make it possible to organize the production process with minimum expenses, to increase the flexibility of management, which leads to savings of material and monetary resources and increases profit.

The monetary expenses are separated from the cost in the form of expenses and take the form of the production cost in the process of circulation and turnover of funds in the market conditions. So, the cost price is expressed in monetary form the current expenses of the enterprise for production and sale of products. These expenses by their economic content can be grouped as follows:

1) material costs (without recyclable waste - residues of raw materials, materials, half-finished products, coolants);

2) labor costs;

3) assignments for state social insurance;

4) assignments for compulsory medical insurance;
5) amortization of fixed assets;

6) other expenses.

Production cost price is formed at the level of the shops of the enterprise, and the total cost price is the sum of expenses connected with the production of products and the costs of its sale (commercial costs-packaging, storage, loading, transportation and advertising).

At development stages of new products its cost price is calculated only as a probabilistic forecast value. Various methods of forecasting estimation are used.

The cost price is the basis for determination of the prices for production. Its reducing leads to an increasing of the sum of profit and the level of profitability. To achieve cost price reduction, it is necessary to know its composition, structure and factors of its dynamics. All this is the subject of statistical study in the analysis of cost price.

Correlation-regression analysis allows determine the relationship between indices of enterprise activity and factors which influence for these indices. So, with the help of multiple regression analysis, the influence of one or more independent factors on the dependent one is studied.

The basic method of solving the problem of finding the parameters of the regression equation is the OLS. It consists in minimizing the sum of the squares of the errors of the actually measured values of the dependent variable from its values of «true» line.

Any phenomenon, including the economic phenomenon, is determined by the lot of together and collectively acting factors. So, dependence of one dependent variable $y$ (resulting sign) on several explaining variables $x_{1}, x_{2}, \ldots x_{m}$ (factors or factor signs) in conditions of specified place and time is studied.

So, as a resulting sign, it is possible to choose the cost of sales, and as factors - the listed above groups of costs: material costs, labor costs, deductions for state social insurance, etc. The coefficients of correlation are calculated to determine the factors that exert the greatest influence on the resultant attribute.

Let's consider the linear relationship between the dependent variable $y$ and the explanatory variables $x_{1}, x_{2}, \ldots x_{m}$.

Then the regression model is written as:

$$
y=\beta_{0}+\beta_{1} x_{1}+\beta_{2} x_{2}+\ldots+\beta_{m} x_{m}+\varepsilon,
$$

where $\varepsilon$ shows the error of the empirical value from the values of «true» line, the coefficients $\beta_{k}(k=0, \ldots m)-$ the regression parameters or the coefficients of multiple regression.

Then the forecasted value $\hat{y}$ of value $y$ is written as:

$$
\widehat{y}=b_{0}+b_{1} x_{1}+b_{2} x_{2}+\ldots+b_{m} x_{m},
$$

where $b_{k}(k=0, \ldots m)$ - estimations of parameters of $\beta_{k}(k=$ $=0, \ldots m)$.

For a constant $\beta_{0}$ in the regression equation introduce the variable $x_{0}$, which takes the value of 1 for all $i=1, \ldots, n: x_{i o} \equiv 1$.

Then the linear model of the dependence can be represented in the form:

$$
y=\beta_{0} x_{0}+\beta_{1} x_{1}+\ldots \beta_{m} x_{m}+\varepsilon .
$$

The results of observations $y_{1}, y_{2} \ldots y_{n}$ are written in the form of a vector-column of dimension $n \times 1$. Let's write 
the values of the variables $x_{0}, x_{1}, \ldots x_{m}$ in the form of a matrix $X$ of dimension $n \times(m+1)$ and the residuals of the regression function - in the form of a vector-column of dimension $n \times 1$. The regression parameters $\beta_{k}(k=0, \ldots m)$ write in form a vector-column $\beta$ of dimension $(m+1) \times 1$. Let's represent:

$$
\begin{aligned}
& y=\left[\begin{array}{l}
y_{1} \\
y_{2} \\
\cdot \\
\cdot \\
\cdot \\
y_{n}
\end{array}\right] ; \quad X=\left[\begin{array}{l}
1 x_{11} \ldots x_{1 m} \\
1 x_{21} \ldots x_{2 m} \\
\ldots \\
1 x_{n 1} \ldots x_{n m}
\end{array}\right] ; \\
& \varepsilon=\left[\begin{array}{l}
\varepsilon_{1} \\
\varepsilon_{2} \\
\cdot \\
\cdot \\
\varepsilon_{n}
\end{array}\right] ; \quad \beta=\left[\begin{array}{l}
\beta_{0} \\
\beta_{1} \\
\cdot \\
\cdot \\
\cdot \\
\beta_{m}
\end{array}\right] .
\end{aligned}
$$

The forecasted value $\hat{y}$ of value $y$ can be represented as follows:

$$
\hat{y}=X b,
$$

and the function $y$ is, respectively,

$$
y=X \beta+\varepsilon .
$$

To find the vector of unknown parameters in (6), let's apply the method of least squares. The sum of the squares of the errors of the empirical value from the values of «true» line should be minimal, i. e.:

$$
S=(y-X \beta)^{\prime}(y-X \beta)=\varepsilon^{\prime} \varepsilon \rightarrow \min ,
$$

when differentiate this expression on the elements of the vector $\beta$, equate the resulting expression to zero and if the matrix $X^{\prime} X$ is reversible for estimations $b_{k}(k=0, \ldots m)$ obtain:

$$
b=\left(X^{\prime} X\right)^{-1} X^{\prime} y .
$$

After the some transformations, it is obtained:

$$
\sum_{i=1}^{n}\left(y_{i}-\bar{y}\right)^{2}=\sum_{i=1}^{n}\left(\widehat{y}_{i}-\bar{y}\right)^{2}+\sum_{i=1}^{n}\left(y_{i}-\widehat{y}_{i}\right)^{2}
$$

It is obtained $T S S=E S S+R S S$, where $T S S$ - the total sum of squares, ESS - «explained» sum of squares, RSS the residual sum of the squares. By (9) $\sum_{i=1}^{n} \frac{\left(\hat{y}_{i}-\bar{y}\right)^{2}}{\left(y_{i}-\bar{y}\right)^{2}}-$ part of the total sum of squares, explained by the regression equation. This ratio is known as the coefficient of determination $R^{2}$ [10-12]:

$$
R^{2}=\frac{\sum_{i-1}^{n}\left(\hat{y}_{i}-\bar{y}\right)^{2}}{\sum_{i=1}^{n}\left(y_{i}-\bar{y}\right)^{2}},
$$

or it is obtained $R^{2}=E S S / T S S$. With the help of the multiple coefficients of correlation $R$ the practical significance of the regression equation, tightness of relationship between the resulting sign and factors is evaluated. The nearer $R$ to 1 , the more the model can be considered adequate to experimental data and it is possible to conduct economic analysis and forecasting based on this model.

To test the regression quality it is necessary to find the significance with the help a random variable that has a Fisher-Snedecor distribution with the number of degrees of freedom $k_{1}=k-1, k_{2}=n-k$, or $F$-statistics or a Fisher-Snedecor distribution quantile. It is equal:

$$
F=\frac{E S S /(k-1)}{R S S /(n-k)}=\frac{\sum_{i=1}^{n}\left(\hat{y}_{i}-\bar{y}\right)^{2} /(k-1)}{\sum_{i=1}^{n}\left(y_{i}-\widehat{y}_{i}\right)^{2} /(n-k)},
$$

where $k$ - the number of estimated parameters in the regression equation, $n$ - the number of observations.

After the some transformations:

$$
F=\frac{R^{2} /(k-1)}{\left(1-R^{2}\right) /(n-k)} \text {. }
$$

If the founded value $F_{c a l c}>F_{c r}$, the null hypothesis is reject and it is conclude that the existing «explanation» of the behavior of the quantity $y$ is better than it could be obtained by chance. Critical levels $F_{c r}$ are searched at an appropriate level of significance, for example, $5 \%$ and number of degrees of freedom $k_{1}$ and $k_{2}$.

The significance of the multiple correlation coefficient is verify with the help of a random variable that has a Student distribution with number of degrees of freedom $k_{1}=n-k-1$ :

$$
T=\frac{R \sqrt{n-k-1}}{\sqrt{1-R^{2}}},
$$

where $R$ - the multiple coefficient of correlation.

Let's find the critical value of the quantity $T_{c r}$ taking into account that the number of degrees of freedom $k_{1}$ and the significance level, for example, $5 \%$. If $T_{c a l c}>T_{c r}$, then the multiple coefficient of correlation is significant, and such factors should be used for the forecast evaluation of the resulting sign.

The main factor in reducing the cost of production and improving the level of profitability of enterprises is the solution of the problem of resource saving, which involves improving the process of resource consumption by introducing innovations, reducing production costs. Resource saving is a complex of measures to reduce the resource costs The main factor in reducing the cost of production and improving the profitability level of the enterprises is the solution of the problem of resource saving, which involves improving the process of resource consumption by introducing innovations, reducing production costs, which ensure a reduction in the resource intensity of productions, and, as a result, the growth of production efficiency due to the most rational use of them. It assists to solving the problem of increasing production needs in resources mainly through saving. Economic efficiency is consists in the ratio of the useful result and the costs of production factors. Therefore, the rational use of resources 
provides for achievement the maximum effectiveness of their use at the current level of development of technics and technology.

\section{Research results}

Let's construct an economic-mathematical model of the dependence of sales of the dairy industry enterprise PJSC «Wimm-Bill-Dann Ukraine» (Kyiv region, Ukraine) from the operating costs of the enterprise: material costs, labor costs, deductions for social needs, amortization and other operating expenses.

Operating costs and costs of sales of PJSC «WimmBill-Dann Ukraine» during 2009-2015 are presented in Table 1.

As can be seen from the Table 1 in the structure of cost of sales the greatest part fell on material costs. Tendencies of reducing absolute expenses and their structure are conditioned upon the growth of competition in the production market.

The matrix of pair coefficients of correlation is presented in Table 2.

An analysis of the matrix of pair coefficients of correlation allows make a selecting of factor indications that can be included in model of multiple correlation dependence. It is obtained that the first, third and fourth factor signs can be included in the model.

Let's construct the regression equation describing the relationship between the cost of sales and operating costs material costs, labor costs, deductions for social needs, amortization, other operating expenses.

Operating costs and costs of sales of PJSC «Wimm-Bill-Dann Ukraine» (Kyiv region, Ukraine)

\begin{tabular}{|c|c|c|c|c|c|c|c|}
\hline Costs & 2009 & 2010 & 2011 & 2012 & 2013 & 2014 & 2015 \\
\hline Material costs & 453272 & 522895 & 711787 & 660252 & 734600 & 793749 & 875404 \\
\hline Labor costs & 57151 & 72428 & 57270 & 14584 & 75836 & 73355 & 79290 \\
\hline $\begin{array}{l}\text { Deductions for } \\
\text { social needs }\end{array}$ & 19142 & 24824 & 29688 & 33973 & 26012 & 24784 & 27260 \\
\hline Amortization & 25836 & 27746 & 35646 & 53193 & 64143 & 34535 & 61679 \\
\hline $\begin{array}{l}\text { Other operating } \\
\text { expenses }\end{array}$ & 68878 & 159658 & 184341 & 287002 & 139879 & 107783 & 111041 \\
\hline The cost of sales & 514860 & 768845 & 830025 & 887780 & 988363 & 982500 & 1106768 \\
\hline
\end{tabular}

Note: date of PJSC «Wimm-Bill-Dann Ukraine».

Matrix of pair coefficients of correlation

\begin{tabular}{|c|c|c|c|c|c|c|}
\hline $\begin{array}{c}\text { Resulting sign } \\
\text { and factors }\end{array}$ & $y$ & $x_{1}$ & $x_{2}$ & $x_{3}$ & $x_{4}$ & $x_{5}$ \\
\hline$y$ & 1 & 0.940086 & 0.271585 & 0.51355 & 0.760704 & 0.168682 \\
\hline$x_{1}$ & 0.940086 & 1 & 0.284344 & 0.443813 & 0.678447 & 0.036658 \\
\hline$x_{2}$ & 0.271585 & 0.284344 & 1 & -0.58877 & -0.00183 & -0.78278 \\
\hline$x_{3}$ & 0.51355 & 0.443813 & -0.58877 & 1 & 0.502668 & 0.903266 \\
\hline$x_{4}$ & 0.760704 & 0.678447 & -0.00183 & 0.502668 & 1 & 0.264055 \\
\hline$x_{5}$ & 0.168682 & 0.036658 & -0.78278 & 0.903266 & 0.264055 & 1 \\
\hline
\end{tabular}

Note: developed by the author.
Table 2

The regression equation has the form:

$$
y=a_{0}+a_{1} x_{1}+a_{2} x_{2}+a_{3} x_{3}+a_{4} x_{4}+a_{5} x_{5},
$$

where $y$ - cost of sales, thousands of UAH; $x_{1}, x_{2}, x_{3}, x_{3}$, $x_{4}, x_{5}$ - material costs, labor costs, deductions for social needs, amortization, other operating expenses, thousands of UAH; $a_{i}(i=0,1 . .5)$ - parameters of regression.

The analysis is carried out with the help of Excel. The equation is obtained:

$$
\begin{aligned}
& y=8027.264971+1.000955 x_{1}+2.8936104 x_{3}+ \\
& +2.40821339 x_{4},
\end{aligned}
$$

which describes the relationship between the cost of sales and operating costs - material costs, labor costs, deductions for social needs, amortization, other operating expenses. The multiple coefficient of the correlation $R$ is 0.9566841 , the coefficient of determination $R^{2}$ is 0.91524451 , which indicates that the model can be considered adequate to experimental data and based on this model it is possible to conduct economic analysis and forecasting of the cost of sales of the enterprise.

Let's check the significance of the model (15). Let's obtain $F_{\text {calc }}$ for the obtained model in the Excel. $F_{\text {calc }}=10.798$. Let's determine the critical value of the Fisher-Snedecor distribution, taking into account that the number of degrees of freedom $k_{1}, k_{2}$, and the significance level is $5 \%$. $F_{c r}=9.2766$. For the obtained model $F_{c a l c}>F_{c r}$. From this it follows that the model is significant and can be used for analysis and forecasting.

This model allows estimate the dependence

Table 1 of the change of the cost of sales from changes of material costs, labor costs, deductions for social needs, amortization and other operating expenses with a sufficiently high accuracy (95\%).

Let's find $T_{\text {calc }} . T_{\text {calc }}=5.684$. Let's find the critical value of the quantity taking into account that the number of degrees of freedom $k_{1}$ and the significance level is $5 \% . T_{c r}=3.182$.

Since $T_{\text {calc }}>T_{c r}$, then the multiple coefficient of correlation is significant, and the next factors are used - material costs, deductions for social needs, amortization for the forecasting estimation of the cost price of dairy production. This model allows estimate the dependence of the changing of the cost of sales from the changes of operating costs with a sufficiently high accuracy (95\%).

It follows from the conducted correlationregression analysis that for the reducing of the cost price of production, it is necessary to reduce the material costs at the enterprise and also other costs. The complex of measures can include various measures, including resourcesaving measures. Operating costs and costs of sales of PJSC «Eurocement-Ukraine» (Kharkiv region, Ukraine) during 2009-2015 are presented in Table 3.

As can be seen from the Table 3 in the structure of cost of sales the greatest part fell on material costs. Tendencies of reducing absolute expenses and their structure are conditioned upon the growth of competition in the production market. 
Let's consider the dependence of net income of the enterprise from the cost of sales. The output data are presented in Table 4.

Let's construct the regression equation describing the relationship between the net income of the enterprise and the cost of sales. The regression equation has the form:

$$
y=a_{0}+a_{1} x
$$

where $y$ - net income of the enterprise, thousands of UAH; $x$ - cost of sales, thousands of UAH; $a_{0}, a_{1}$ - parameters of regression.

The corresponding analysis is carried out with the help of Excel. The following regression equation is obtained:

$$
y=34650.30778+1.11704279 x,
$$

which describes the relationship between the net income of the enterprise and the costs of sales. From the received equation of regression (17) it is visible that the net income of the enterprise grows with growth of the cost of sales. The multiple coefficients of correlation is 0.972 , the coefficient of determination is 0.945 , which indicates that the model can be considered adequate to experimental data and allows to conduct economic analysis and forecasting of the net income of the company.

Using the revealed dependence and the trend equations, the forecasting of net income during 2016-2017 is obtained. It is presented in Fig. 1, 2.

Analysis of these graphics shows that the most adequate to experimental data is a model which represented by a polynomial trend line. Also, the obtained trend lines allow forecast the level of net income of the enterprise during several years ahead.

Operational costs and costs of sales of PJ5C «Eurocement-Ukraine» (Kharkiv region, Ukraine)

\begin{tabular}{|l|c|c|c|c|c|c|c|}
\hline Costs & 2009 & 2010 & 2011 & 2012 & 2013 & 2014 & 2015 \\
\hline Material costs & 905103 & 1050027 & 1162498 & 852225 & 859477 & 617273 & 513587 \\
\hline Labor costs & 43400 & 44056 & 47333 & 42256 & 42334 & 40617 & 31912 \\
\hline $\begin{array}{l}\text { Deductions for } \\
\text { sacial needs }\end{array}$ & 17816 & 18124 & 17317 & 15872 & 15404 & 13573 & 10331 \\
\hline Amortization & 34040 & 31433 & 30849 & 35185 & 35889 & 37570 & 38667 \\
\hline $\begin{array}{l}\text { Other operating } \\
\text { expenses }\end{array}$ & 151284 & 151428 & 165595 & 107782 & 232626 & 764698 & 85734 \\
\hline \begin{tabular}{l} 
The cost of sales \\
\hline
\end{tabular} & 1067948 & 1115900 & 1199375 & 921214 & 936110 & 690623 & 579533 \\
\hline
\end{tabular}

Note: data of PJSC «Eurocement-Ukraine».

Output for constructing the regression equation

\begin{tabular}{|l|c|c|c|c|c|c|c|}
\hline $\begin{array}{l}\text { Net } \\
\text { income, } \\
\text { cost of sales }\end{array}$ & 2009 & 2010 & 2011 & 2012 & 2013 & 2014 & 2015 \\
\hline Net income & 1306463 & 1182794 & 1374123 & 1134838 & 1053014 & 804662 & 659392 \\
\hline The costs of sales & 1067948 & 1115900 & 1199375 & 921214 & 936110 & 690623 & 579533 \\
\hline
\end{tabular}

Note: data of PJCS «Eurocement-Ukraine».
Table 4

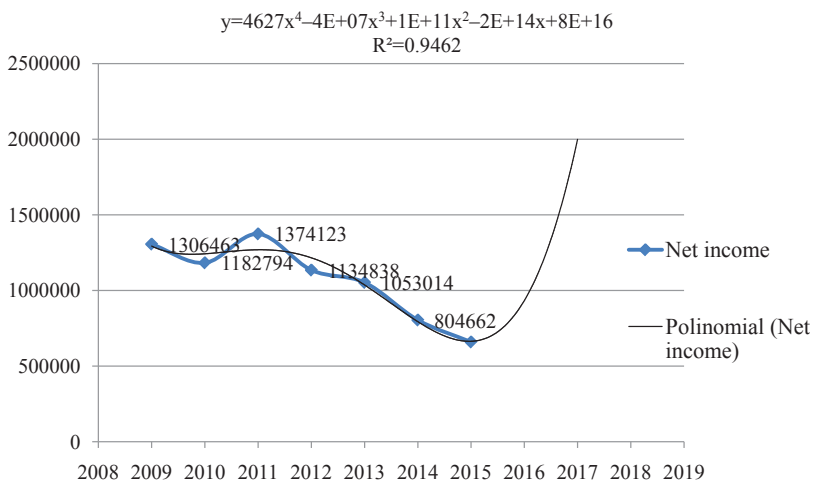

Fig. 1. Forecasted level of net income at PJSC «Eurocement-Ukraine», a polynomial trend line

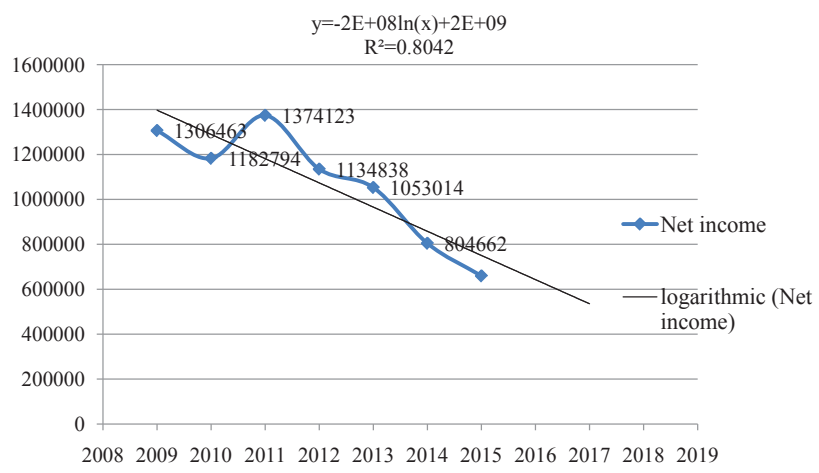

Fig. 2. Forecasted level of net income at PJSC «Eurocement-Ukraine», a logarithmic trend line

\section{SWOT analysis of research results}

Strengths. A detailed analysis of the activities of several Ukrainian enterprises should be noted among the strengths of this research. Economic-mathematical models in the form of multiple regression equations are constructed on the basis of statistical data of several industrial enterprises of Ukraine, with the help of which it is possible to analyze and forecast indices of the economic efficiency of enterprises activity. A detailed verification of the adequacy of the developed mathematical models is given with the help of calculating the FisherSnedecor and Student quantiles of the distribution.

Weaknesses. Among the weaknesses of the research should be noted a small number of enterprises for which a detailed analysis of economic activities is carried out.

Opportunities. In further studies it is expediently to develop economicmathematical models for a larger number of enterprises and to estimate the dependence of that how in the per- 
centage expression the reduction in resource expenses will affect on the economic effect of such measures.

Threats. Despite the relatively large number of foreign studies in the field of construction of economic-mathematical models of indices of enterprise activity, it should be noted that economic-mathematical models of indices of enterprise activity of Ukraine are built for a small number of enterprises.

\section{Conclusions}

1. The analysis of the cost of sales of several enterprises of dairy and constructing industries of Ukraine is carried out. This analysis helped to reveal that in the cost structure the greatest part is fell on material costs. With the help of the correlation-regression analysis the factors that have the greatest impact on the cost of sales are identified - the first, third and fourth factor signs are included in the model for the studying industrial enterprise.

2. Regression equations are constructed describing the relationship between the cost of sales and the factors that affect its result, as well as the net income of the enterprise with the cost of sales. It is shown that the models that are represented by the linear equations of multiple regression are adequate to experimental data. The parameters of the regression equations are determined with the help of OLS.

3. On the basis of the found multiple coefficients of correlation $R$ and determination $R^{2}$, it is determined that the constructed models are adequate to experimental data and can be used for analysis and forecasting. This is evidenced by the high level of multiple correlation and determination coefficients $(0.9566841$ and 0.91524451$)$ for the first and (0.972 and 0.945$)$ for the second model

The values of $F$-statistics and $T$-criterion show the significance of the model of the cost of sales and the correlation coefficient. The economic-mathematical model is obtained, which allows estimating the dependence of the change in the cost of sales of the dairy industry enterprise of Ukraine from the change of the expenses of the enterprise with a sufficiently high accuracy (95\%).

4. Linear and polynomial trends are constructed for forecasting of the net income of the enterprise of the construction industry of Ukraine for several years ahead. It is obtained that the model represented by the polynomial trend line is the more adequate to the experimental data, that is, the dependence of the net income from the year is polynomial for the researching enterprise.

The obtained models can be used for analysis, forecasting and management of indices of enterprise activity in the system of efficient use of enterprise resources.

\section{References}

1. Afanasiev, N. V. Ekonomika predpriiatiia [Text]: Tutorial N. V. Afanasiev, A. B. Goncharov. - Kharkiv: INZhEK, 2004. $518 \mathrm{p}$.

2. Davidovich, I. E. Kontrolinh [Text]: Tutorial / I. E. Davidovich. - Kyiv: Tsentr uchebnoi literatury, 2008. - 552 p.

3. Sidun, V. Ekonomika pidpryiemstva [Text]: Tutorial / V. Sidun, Yu. Ponomarova. - Kyiv: Tsentr navchalnoi literatury, 2003. 435 p.

4. Dolgushevskii, F. G. Selskohoziaistvennaia statistika s osnovami ekonomicheskoi statistiki [Text] / F. G. Dolgushevskii, O. G. Hristich. - Moscow: Statistika, 2006. - 311 p.

5. Zahorianska, O. L. The effect of depreciation on production costs of modern enterprises in the context of competitive environment [Text] / O. L. Zahorianska, Y. Y. Karlik, A. A. Uglava // Herald of Khmelnytskyi National University. - 2016. Vol. 1, № 2. - P. 56-61.

6. Bourbonnais, R. The Contribution of Econometrics to the Management of the Enterprise [Text] / R. Bourbonnais, M. Maftei // Romanian Journal of Economic Forecasting. - 2012. - № 1. P. $144-155$.

7. Lefter, C. Marketing researches. Theory and applications [Text]/ C. Lefter. - Brasov, Romania: Infomarket Publishing House, 2004. - P. 101-104.

8. Vuchkov, I. Prikladnoi lineinyi regressionnyi analiz [Text] I. Vuchkov, L. Boiadzhieva, E. Solakov. - Moscow: Finansy i statistika, 1987. - 239 p.

9. Milev, O. Factor analisis of cost of production in the production and processing of meat and meat products in the Stara Zagora [Text] / O. Milev // Trakia Journal of Sciences. - 2015. Vol. 13, Suppl. 1. - P. 337-339. doi:10.15547/tjs.2015.s.01.057

10. Tudorel, A. Econometrie [Text] / A. Tudorel, R. Bourbonnais. Bucharest, 2008. - $400 \mathrm{p}$.

11. Draper, N. R. Applied Regression Analysis [Text] / N. R. Draper, H. Smith. - Ed. 3. - John Wiley \& Sons, 1998. - 736 p. doi:10.1002/9781118625590

12. Krastin O. P. Razrabotka i interpretatsiya modeley korrelyatsionnyih svyazey v ekonomike [Text] / O. P. Krastin - Riga: Zinatne, 1983. - 305 p.

\section{ПРОГНОЗИРОВАНИЕ СЕБЕСТОИМОСТИ ПРОДУКЦИИ И ДРУГИХ ПОКАЗАТЕЛЕЙ ДЕЯТЕЛЬНОСТИ ПРОМЫШЛЕННОГО ПРЕДПРИЯТИЯ}

Исследована взаимосвязь между себестоимостью реализованной продукции и операционными затратами, а также между чистым доходом и себестоимостью реализованной продукции нескольких промышленных предприятий. Разработаны экономико-математические модели в виде уравнения множественной регрессии на основе статистических данных нескольких промышленных предприятий Украины. Проверена адекватность моделей экспериментальным данным.

Ключевые слова: экономико-математические модели, уравнение множественной регрессии, множественные коэффициенты корреляции и детерминации.

Gritcyuk Katerina, PhD, Senior Lecturer, National Technical University «Kharkiv Polytechnic Institute», Ukraine, e-mail. gricekaterina12@gmail.com, ORCID: http://orcid.org/0000-00033241-9482 